\title{
Peningkatan Pengetahuan Tentang Keamanan Bandar Udara Pada Penyelengaraan Jamaah Ibadah Umroh Melalui Penyuluhan Online
}

\author{
Laila Rochmawati ${ }^{1}$, Dewi Ratna Sari ${ }^{2}$, Didi Hariyanto ${ }^{3}$, Fatmawati $^{4}$, Lady Silk Moonlight ${ }^{5}$, \\ Faoyan Agus Furyanto ${ }^{6}$ \\ 1,2,3,4,5,6 Politeknik Penerbangan Surabaya \\ e-mail: 1'lailarochmawati@poltekbangsby.ac.id, 2dewhy.r69@gmail.com, \\ ${ }^{3}$ didiharyanto1965@gmail.com, ${ }^{4}$ fatmawati.0280@gmail.com, ${ }^{5}$ lady@poltekbangsby.ac.id
}

\begin{abstract}
Abstrak
Sasaran dari penyuluhan ini adalah jamaah umroh dan guru smk penerbangan yang belum paham tentang keamanan bandara. Identifikasi masalah pemahaman Jamaah ibadah umroh guru SMK penerbangan akan keamanan bandar udara masih relative rendah;pengetahuan barang-barang berbahaya jamaah ibadah umroh rendah; travel yang belum memberikan penyuluhan tentang keaman bandar udara. Pemecahan masalah yaitu dengan meningkatkan pemahaman jamaah ibadah umroh tentang keamanan bandar udara dengan memberikan penyuluhan tentang keamanan bandar udara; meningkatkan pengetahuan barang-barang berbahaya jamaah ibadah umroh; memberikan penyuluhan lewat travel tentang keamanan bandar udara. Alternatif pemecahan masalah yang diambil penyuluhan keamanan bandar udara pada jamaah ibadah umroh. Tahapan dan metode pelaksanaan program survey sasaran peserta; persiapan saran Prasarana; metode Penyuluhan Bandar Udara; evaluasi program; pelapor.
\end{abstract}

Kata Kunci : keamanan penerbangan, jamaah umroh, penyuluhan online

Abstract

The target of this counseling is Umrah pilgrims and high school aviation teachers who do not understand airport security. The identification of problems with the understanding of pilgrims' umrah pilgrimage for smk aviation teachers on airport security is still relatively low; knowledge of dangerous goods for pilgrims is low; travel that has not provided information about airport safety. The solution to the problem is by increasing the understanding of the Umrah pilgrims about airport security by providing information about airport safety; increase knowledge of dangerous goods for pilgrims to worship Umrah; provide travel education about airport safety. Alternative solutions to problems taken by airport security counseling for Umrah pilgrims. The stages and methods of implementing the target participant survey program; preparation of infrastructure advice; Airport Extension methods; program evaluation; reporting.

Keywords : aviation security, pilgrimer, online sosilisation

\section{Pendahuluan}

Kegiatan ibadah umrah mempunyai dua sisi standar pelaksanaan yang wajib diketahui oleh para jamaah. Aspek utama yang harus diperhatikan dalam pembinaan dan pelatihan yaitu standar pelaksanaan saat jamaah masih di Indonesia. Unsur transportasi, terutama pada pemahamaan keamanan bandar udara sering diabaikan oleh penyelenggara perjalanan. Padahal aspek ini sangat penting dan bermanfaat bagi jamaah umroh yang akan menunaikan ibadah di tanah suci. Pemberian pengetahuan tentang hal itu bisa diberikan pada waktu bimbingan manasik umroh. Pemahaman yang kurang akan barang barang berbahaya yang seringkali dibawa oleh jamaah umroh akan mengakibatkan suatu kejadian yang berbahaya. Seperti kita ketahui bersama, bandar udara merupakan tempat perpindahan penumpang dan barang pesawat udara. Definisi dari muatan atau barang berbahaya adalah barang atau bahan yang dapat 
membahayakan kesehatan, keselamatan jiwa dan harta benda serta keamanan dan keselamatan penerbangan.

Keamanan penerbangan adalah suatu tindakan yang diperlukan untuk melindungi para pengguna transportasi udara dari tindakan melawan hukum. Jalan masuk (access control) yang akan dilalui oleh para pengguna transportasi udara ke area keamanan terbatas di bandara harus diatur. Hal ini sejalan dengan ketentuan peraturan internasional yang tercantum dalam (ICAO Annnexes dan Documents) yang didukung oleh kemajuan perkembangan teknologi informasi digital saat ini, untuk memudahkan dalam melakukan pengawasan dan pengendalian pada area keamanan penerbangan.

Pengawasan keamanan penerbangan dilakukan oleh Inspektur Keamanan Penerbangan, baik dari kantor pusat direktorat jenderal perhubungan udara maupun dari kantor otoritas bandara udara wilayah III. Untuk mengetahui pemenuhan akan peraturan dapat dilakukan pengawasan keamanan penerbangan yang berkelanjutan. keamanan penerbangan. Pengawasan keamanan penerbangan dilaksanakan oleh penyedia jasa penerbangan atau institusi yang berkaitan dengan keamanan penerbangan seperti: ispeksi, survey, pengujian (test), dan audit.

Kendala yang terjadi dalam masyarakat yang menggunakan bandara adalah masih rendahnya tingkat kedisiplinan dan kesadaran masyarakat pengguna jasa transportasi udara, budaya masyarakat yang masih sangat erat kekeluargaannya, terbatasnya pengguna jasa transportasi udara dalam penggunaan teknologi aplikasi online, perbedaan kebijakan antar negara-negara terhadap implementasi penanganan pandemic covid-19.

Daerah keamanan terbatas bandar udara yaitu daerah keberangkatan penumpang antara pemeriksaan keamanan(SCP) dan pesawatudara, daerah service road, apron, fasilitas perbaikan pesawat udara (hangar), tempat penyiapan bagasi (baggage makeup area), tempat penurunan dan pengambilan bagasi tercatat, gedung terminal kargo, daerah penempatan bagasi tercatat dan kargo yang telah diperiksa dan akan dimuat ke pesawat udara, runway dan taxiway, shoulder, daerah sisi udara jasa boga (catering), fasilitas pembersihan pesawat udara.

\section{Metode}

Kegiatan penyuluhan online ini merupakan kegiatan pengabdian kepada masyarakat politeknik penerbangan Surabaya khususnya program studi D3. Komunikasi Penerbangan. Dosen PDPT prodi D3. KP semuanya terlibat dalam kegiatan ini dibantu dengan taruna prodi D3. KP. Kegiatan ini diketuai oleh Laila Rochmawati selaku ketua program studi D3. Komunikasi Penerbangan dan berlangsung pada tanggal 30 September 2020. Wahyu Subagyo dan Didi hariyanto didampingi oleh dosen PDPT prodi D3. Komunikasi Penerbangan. sebagai narasumber yang memaparkan penyuluhan peraturan keamanan penerbangan dalam menjalankan perjalanan udara.

Kegiatan PKM ini menggunakan metode ceramah. Peningkatan pengetahuan dari peserta penyuluhan diukur menggunakan kuesioner yang dibagi sebelum dan sesudah penyuluhan. Sesuai dengan judul penelitian ini yaitu peningkatan pengetahuan tentang keamanan bandar udara pada penyelengaraan jamaah ibadah umroh melalui penyuluhan online, maka pendekatan yang dilakukan dalam penelitian ini adalah dengan menggunakan pendekatan deskriptif kualitatif yang menjadi alat atau media bagi peneliti dalam melakukan analisis data yang ada. Analisis yang di hasilkan dari penelitian ini dapat menemukan sebuah kesimpulan dari hasil kegiatan PKM. Jenis penelitian ini masuk dalam kriteria penelitian kualitatif dilihat dari sisi pendekatannya. Penelitian kualitatif adalah penelitian dengan sasaran penelitian terbatas. Untuk mencapai keberhasilan sasaran penelitian ini, maka data mengenai sasaran kegiatan ini digali sebanyak mungkin untuk diteliti lebih dalam. Penelitian ini masuk dalam area penelitian deskriptif dilihat dari sisi penjelasannya. Penelitian deskriptif adalah penelitian dengan tujuan 
pengumpulan fakta dan penguraian sesuai dengan permasalahan yang diangkat, secara keseluruhan dan teliti. Dari definisi tersebut diatas, maka disimpulkan penelitian ini adalah penelitian deskriptif kualitatif. Objek dari penelitian ini adalah jamaah ibadah umroh dari Travel Nur Ramadhan yang beralamat di Jl. Ketintang Madya, No. 165, Surabaya yang berjumlah 50 jamaah, PT. Alhijar Indowisata, Graha Al Hijaz, Jl. Dewi Sartika No. 239 A, Cawang, Jakarta Timur 13630 Indonesia, yang berjumlah 50 jamaah, Al- Jihad J1 . Jemursari Utara No. 3 Wonocolo Surabaya yang berjumlah 22 jamaah.

\section{Hasil dan Pembahasan}

Penyuluhan peningkatan pengetahuan tentang keamanan bandar udara pada penyelengaraan jamaah ibadah umroh melalui penyuluhan online dalam rangka mewujudkan penerbangan yang aman, nyaman, dan selamat sampai tujuan. Keamanan dan keselamatan adalah faktor utama dalam sektor transportasi udara, melalui penyuluhan online para penumpang diharapkan mendapatkan pengetahuan tentang penerbangan untuk mencegah tindakan yang tidak aman, dan diharapkan kondisi lingkungan yang tidak aman dapat berkurang dan diperbaiki. Kegiatan ini, juga diharapkan dapat mencegah resiko terjadinya kecelakaan, yang dapat merusak peralatan penerbangan bahkan menghilangkan nyawa seseorang. Untuk mewujudkan awareness, tidak hanya dibutuhkan kesadaran dan kepedulian bersama dari regulator dan pelaku industri penerbangan saja, namun penting juga untuk penumpang pesawat udara dalam meningkatkannya.

Faktanya masih banyak masyarakat yang sebenarnya sudah memahami peraturan standar keselamatan yang harus dilakukan oleh seorang penumpang pesawat udara, tapi pada pelaksanaannya - dapat dikatakan masih jauh dari standar keselamatan yang harus dilakukan oleh seorang penumpang pesawat udara. Hal yang kecil saja, pesawat telepon yang masih menyala di dalam pesawat udara, seat belt yang tidak digunakan, membawa barang-barang yang dilarang di dalam pesawat udara seperti gunting, pisau, korek api, merupakan salah satu contoh barang sering terbawa dalam perjalanan menggunakan pesawat udara. Apalagi dengan berkembangnya teknologi dan rentetan peristiwa yang terjadi belakangan ini, semua petugas dan masyarakat perlu menumbuhkan dan meningkatkan kepedulian akan pentingnya pengetahuan tentang keselamatan operasional penerbangan.

Keselamatan penerbangan adalah salah satu aspek utama dalam bidang transportasi udara yang tidak dapat ditoleransi atau dipertanyakan, untuk itu sosialisasi yang terus menerus dan berkelanjutan dinilai sangat diperlukan dalam tahap ini sehingga kesadaran masyarakat akan pentingnya mematuhi peraturan keselamatan penerbangan dapat semakin meningkat. Selain itu upaya-upaya peningkatan keselamatan penerbangan juga bertujuan adanya kesamaan pemahaman antara regulator dengan pelaku industri penerbangan agar tidak terjadi multitafsir. Moda transportasi udara masih menjadi salah satu pilihan masyarakat saat ini dalam berpergian karena dapat diandalkan serta efektif dan efisien. Dengan tingginya kebutuhan masyarakat akan transportasi udara, maka pemerintah dituntut untuk selalu menjaga keselamatan penerbangan semaksimal mungkin.

Sebagaimana amanah dari icao annex 19, kita sebagai salah satu negara anggota icao berkewajiban untuk melaksanakan safety oversight untuk memastikan operasional penerbangan di Indonesia dengan peraturan dan perundang-undangan yang berkaitan dengan keselamatan penerbangan. Keselamatan penerbangan akan terwujud dan akan semakin meningkat apabila ada sinergi dari regulator dan stakeholder / operator pernerbangan, maka saling berkolaborasi, bekerja sama untuk meningkatkan iklim penerbangan indonesia yang selamat, aman, dan nyaman, perlu ditingkatkan. Akhir-akhir ini, terdapat beberapa accident, serious incident, dan incident di indonesia, bahkan pandemi yang menyerang seluruh dunia. Untuk itu, perlu 
diingatkan kembali agar seluruh operator/stake holder kembali meningkatkan kewaspadaan dan juga mengambil kejadian tersebut menjadi pelajaran untuk perbaikan dan menemukan resolusi terkait masalah keselamatan yang efektif. Kami juga berharap tujuan dari kegiatan ini dapat tercapai, yaitu politeknik penerbangan surabaya, direktorat perhubungan udara, operator penerbangan indonesia bersama masyarakat dapat terus berkomitmen untuk membangun penerbangan indonesia. Dan, pada akhirnya tujuan besar yang ingin dicapai adalah pemerintah berhasil menciptakan keselamatan penerbangan yang lebih baik dan terus menekan rate of accident.

Bandar udara merupakan tempat perpindahan penumpang dan muatan pesawat udara termasuk barang berbahaya. Definisi dari bahan / barang berbahaya adalah bahan / barang yang kandungan isinya dapat membahayakan keselamatan jiwa, kesehatan, harta benda serta keselamatan dan keamanan penerbangan. Dengan keamanan bandar udara pada penyelengaraan jamaah ibadah umroh melalui penyuluhan online kami berharap agar semua peserta khususnya bagi para pengguna moda transportasi udara dapat menambah pengetahuan tentang peraturan keamanan bandara sehingga bisa meminimalisir kecelakaan saat melakukan perjalanan udara.

Berikut hasil kuesioner kegiatan keamanan bandar udara pada penyelengaraan jamaah ibadah umroh melalui penyuluhan online yang kami sebarkan pada waktu berakhirnya kegiatan penyuluhan.

1. Para peserta keamanan bandar udara pada penyelengaraan jamaah ibadah umroh melalui penyuluhan online berpendapat bahwa materi penyuluhan disajikan dapat menambah pengetahuan dan wawasan tentang peraturan keamanan penerbangan dalam menjalankan perjalanan udara

2. Penyajian penyuluhan peraturan keamanan penerbangan dalam menjalankan perjalanan udara sangat komunikatif dan interaktif.

3. Materi penyuluhan peraturan keamanan penerbangan dalam menjalankan perjalanan udara dapat membantu dan bermanfaat bagi saya dalam pekerjaan, pengajaran dan perjalanan.

4. Kegiatan selama acara penyuluhan tentang peraturan keamanan penerbangan dalam menjalankan perjalanan udara sangat nyaman dan menarik.

5. Narasumber penyuluhan peraturan keamanan penerbangan dalam menjalankan perjalanan udara sangat menguasai materi peraturan keamanan penerbangan.

6. Kegiatan penyuluhan peraturan keamanan penerbangan dalam menjalankan perjalanan udara sangat bermanfaat dan meningkatkan pemahaman saya, yang dapat saya bagikan kepada rekan kerja, jamaah, teman, saudara, murid dan yang lainnya.

7. Dengan peningkatan pengetahuan tentang keamanan bandar udara pada penyelengaraan jamaah ibadah umroh melalui penyuluhan online diharapkan jamaah umroh sedikit demi sedikit mulai memahami tentang keamanan bandar udara.

Para peserta sosialisasi memiliki pengetahuan tentang ketentuan keamanan penerbangan pada operasional penerbangan di masa pandemi corona virus 2019.

Penyuluhan peraturan keamanan penerbangan dibagi menjadi lima bagian. Pertama sistem keamanan berdasarkan penilaian resiko, kedua upaya pengamanan bagasi kabin, ketiga upaya pengamanan bagasi tercatat. Keempat upaya pengamanan penumpang, adalah tempat / lokasi pemeriksaan keamanan penumpang orang, personel pesawat udara serta barang - barang yang akan dibawa masuk ke area ruang tunggu dan / atau keamanan terbatas di gedung terminal Bandar. Sebagai penerapan pengamanan penumpang di Bandara, terdapat alat pemeriksaan keamanan yaitu Gawang Detektor Logam atau disebut juga Walk Through Metal Detector (WTMD) X-Ray Conveyor Belt. Setiap penumpang dan personel pesawat udara wajib membuka mantel, jaket topi, sabuk, ponsel, arloji, kunci juga barang- barang yang mengandung unsur logam dan meletakan kedalam tas atau wadah yang telah disediakan dan 
kemudian diperiksa melalui mesin xray dan diatur oleh petugas keamanan bandar udara. Petugas tersebut mengatur arus masuk personel pesawat udara, penumpang, berserta barang bawaanya.

Hand-held metal detector adalah alat pendeteksi logam yang ditujukan untuk keamanan Handheld ini digunakan untuk mendeteksi benda yang terbuat dari logam yang dianggap berbahaya seperti senjata tajam senjata api dan bom yang dimana benda itu terbuat dari logam Penggunaan handheld metal detector ini cukup mudah yaitu dengan mengarahkan handheld metal detector ke arah benda atau seseorang yang ingin diperiksa. Walkthrough Metal Detector merupakan pintu keamanan yang dilengkapi metal detector. Pintu tersebut dapat menjangkau hingga 33 zona target lokasi tubuh manusia. Alat ini memungkinkan mendeteksi seluruh bagian tubuh dari kepala hingga kaki, dari kiri hingga kanan secara akurat. X-Ray Security Equipment yaitu peralatan pendeteksi bahan atau barang berbahaya, yang ditampilkan pada display monitor. Bahan atau barang berbahaya meliputi senjata tajam, senjata api, atau benda dari logam yang dianggap berbahaya, bahan peledak, hingga obat-obatan terlarang. Dilakukan hal ini untuk mencegah terjadinya hal-hal yang membahayakan keselamatan dan keamanan penerbangan.

Cairan aerosol dan gel yang dibawa sendiri oleh penumpang sebelum memasuki bandara wajib memenuhi aturan yaitu: wadah berkapsitas maksimal $100 \mathrm{ml}$ atau kurang lebih ukuran sejenisnya, wadah tersebut dimasukan kedalam satu kantong plastik dengan ukuran kurang lebih 1200 centimeter persegi. Pihak pengelola bandar udara dan maskapai penerbangan menyediakan kantong tersebut dengan kapasitas maksimal satu liter atau kurang lebih ukuran sejenisnya, kemudian mensegelnya ulang. Tiap penumpang diijinkan membawa maksimal satu kantong plastik berisi cairan gel dan aerosol.

Dalam Peraturan Direktur Jenderal Perhubungan Udara No. SKEP/43/2007 dijelaskan bahwa penumpang pesawat udara dapat membawa cairan aerosol dan gel kedalam kabin pesawat udara sebagai barang bawaan untuk keperluan sendiri. Barang bawaan tersebut meliputi keperluan sehari-hari, minuman, obat-obatan, kosmetik, dll. Barang bawaan penumpang pesawat udara dapat dibawa sendiri sebelum masuk kedalam bandara, dibeli atau diperoleh di toko bebas pajak atau bea cukai yang ada didalam Bandara (airport duty free shop), atau didalam pesawat udara.

Persyaratan gel dan aerosol tersebut tidak berlaku untuk makanan atau minuman bayi, obat-obatan medis, dan makanan atau minuman penumpang program diet khusus. Jika membawa gel dan aerosol lebih dari persyaratan ketentuan kapasitas tersebut, maka gel dan aerosol harus dimasukan kedalam bagasi yang tercatat (hold baggage), atau dapat disita oleh petugas keamanan bandara. Jika penumpang membeli gel dan aerosol dari toko bebas pajak dan bea cukai yang ada didalam bandara (duty free shop) atau didalam pesawat, maka syarat wajib yang harus dipenuhi yaitu: penumpang menempatkan gel dan aerosol tersebut yang ada dalam suatu wadah, lalu harus dimasukkan dalam kantong plastik yang disediakan oleh pengelola toko bebas pajak atau bea cukai, kemudian mensegel ulang. Bukti pembelian juga harus disiapkan. Kantong plastik yang berisi gel dan aerosol tersebut harus dipisahkan dengan barang bawaan lainnya, pada saat pemeriksaan di bandara.

Kegiatan peningkatan pengetahuan tentang keamanan bandar udara pada penyelengaraan jamaah ibadah umroh melalui penyuluhan online sangat didukung oleh politeknik penerbangan Surabaya, Kantor Otoritas Bandar Udara Wilayah III dan para peserta penyuluhan yang berpartisipasi secara aktif dalam pelaksanaan pelatihan tersebut, secara langsung maupun tidak langsung. Program Studi D3 Komunikasi Penerbangan menyediakan fasilitas tempat kegiatan yang cukup representative untuk melaksanakan penyuluhan tersebut serta dukungan untuk mengikuti kegiatan sosialisasi dengan seksama. 
Kendala-kendala yang dihadapi saat penyuluhan online keamanan bandar udara pada penyelengaraan jamaah ibadah umroh di lingkungan bandara dan guru SMK Penerbangan Indonesia (Kerjasama Dengan Otoritas Banda Udara Juanda), yaitu terbatasnya fasilitas pendukung dalam melakukan penyuluhan dan presentasi, juga waktu yang dibatasi hanya 2 jam penyuluhan. Para peserta penyuluhan mengingikan waktu yang lebih untuk meningkatkan pengetahuan keamanan bandar udara mereka. Penyuluhan online keamanan bandar udara pada penyelengaraan jamaah ibadah umroh di lingkungan bandara dan guru SMK Penerbangan Indonesia (Kerjasama Dengan Otoritas Banda Udara Juanda) merupakan kegiatan yang sangat bermanfaat bagi masyarakat. Diharapkan kepedulian dan kesadaran masyarakat dalam hal keamanan bandar udara sangat meningkat, saat melakukan perjalanan udara.

\section{Kesimpulan}

Peningkatan pengetahuan tentang keamanan bandar udara pada penyelengaraan jamaah ibadah umroh melalui penyuluhan online sangat bermanfaat untuk khalayak umum sehingga bisa meningkatkan pemahaman mereka terkait aturan aturan tentang keamanan bandar udara. Kendala yang dihadapi oleh pemerintah dalam musim pendemi ini adalah:

1. Masih rendahnya tingkat kedisiplinan dan kesadaran masyarakat pengguna jasa transportasi udara.

2. Budaya masyarakat yang masih sangat erat kekeluargaannya.

3. Terbatasnya pengguna jasa transportasi udara dalam penggunaan teknologi aplikasi online.

4. Perbedaan kebijakan antar negara-negara terhadap implementasi penanganan pandemi covid-19.

Pihak Kantor Otoritas Bandar Udara Wilayah III setempat khususnya dilingkungan masyarakat umum diharapkan lebih gencar melakukan penyuluhan keamanan bandar udara. Perlu dilakukan kerjasama antara Perguruan Tinggi, Pemerintah Daerah, dan Kantor Otoritas Bandar Udara Wilayah III tentunya juga untuk meningkatkan kemampuan mereka dalam dalam penyuluhan keamanan bandar udara.

\section{Penghargaan/Ucapan terima kasih}

Penulis menyadari sepenuhnya bahwa keberhasilan penyelesaian penyusunan laporan PKM ini tidak terlepas dari dukungan, bantuan dan bimbingan dari berbagai pihak. Pada kesempatan ini penulis menyampaikan rasa hormat dan terimakasih yang sebesar-besarnya kepada Direktur Politeknik Penerbangan Surabaya atas dukungan yang telah diberikan untuk kegiatan pengabdian kepada masyarakat ini. Kantor Otoritas Bandar Udara Wilayah III dan teman sejawat dosen Politeknik Penerbangan Surabaya atas support yang tiada hentinya. Kepada semua pihak yang tidak dapat disebutkan satu persatu, penulis mengucapkan banyak terima kasih. Semoga bantuan dan dukungan yang diberikan kepada penulis bernilai amal ibadah disisi Allah Subhanahu Wata'ala. Amien

\section{Daftar Pustaka}

Kepmenhub Nomor: KM. 211 Tahun 2020 tentang Program Keamanan Penerbangan Nasional

Kepmenkes Nomor: HK. 01.07/Menkes/382/2020 tentang Protokol Kesehatan Bagi Masyarakat di Tempat dan Fasilitas Umum Dalam Rangka Pencegahan dan Pengendalian Corona Virus Disease (Covid-19) 
Keppres Nomor 11 Tahun 2020 tentang Penetapan Kedaruratan Kesehatan Masyarakat CoronaVirus Disease (Covid-19)

Keppres Nomor 12 Tahun 2020 tentang Penetapan Bencana Non Alam Penyebaran CoronaVirus Disease (Covid-19)

Nomor: HK. 02.01/Menkes/313/2020 tentang Protokol Kesehatan Penanganan Kepulangan WNI dan Kedatangan WNA dari Luar Negeri di Pintu Masuk Negara dan di Wilayah pada Situasi Pembatasan Sosial Berskala Besar (PSBB).

Nomor: SE. 13 Tahun 2020 tentang Operasional Transportasi Udara Dalam Masa Kegiatan Masyarakat Produktif dan Aman dari Corona Virus Disease (Covid-19)

Nomor: SE. 40 Tahun 2020 tentang Pedoman Langkah-langkah Keamanan Penerbangan Dalam Masa Kegiatan Masyarakat Produktif dan Aman dari Corona Virus Disease (Covid19)

Peraturan Pemerintah Nomor 21 Tahun 2020 tentang Pembatasan Sosial Berskala Besar Dalam Rangka Percepatan Penanganan Corona Virus Disease (Covid-19)

Permenhub Nomor: PM. 18 Tahun 2020 tentang Pengendalian Transportasi Dalam Rangka Pencegahan Penyebaran Corona Virus Disease (Covid-19), sebagaimana telah diubah terakhir dengan Permenhub Nomor: PM. 41 Tahun 2020

Permenhub Nomor: PM. 51 Tahun 2020 tentang Keamanan Penerbangan Nasional

Permenkes Nomor: 9 Tahun 2020 tentang Pedoman Pembatasan Sosial Berskala Besar Dalam Rangka Percepatan Penanganan Corona Virus Disease (Covid-19)

Permenkumham Nomor 11 Tahun 2020 tentang Pelarangan Sementara Orang Asing Masuk Negara Republik Indonesia

SE Gugus Tugas Nomor 7 Tahun 2020 tentang Kriteria dan Persyaratan Perjalanan Orang Dalam Masa Adaptasi Kebiasaan Baru Menuju Masyarakat Produktif dan Aman Corona Virus Disease (Covid-19), sebagaimana telah diubah terakhir dengan SE Gugus Tugas Nomor 9 Tahun 2020.

Undang-Undang RI Nomor 1 Tahun 2009 tentang Penerbangan

Undang-Undang RI Nomor 6 Tahun 2018 tentang Kekarantinaan Kesehatan 